\title{
Eating behaviours of university students in Southern Nigeria: an evaluation of sex differences
}

\author{
Judith Nmor ${ }^{1}$, Kehi Harry Nwaka ${ }^{2}$, Jephtha Christopher Nmor ${ }^{2,3, *}$ \\ ${ }^{1}$ Department of Nutrition Sciences, Siebold University, Nagasaki, Japan (formerly) \\ ${ }^{2}$ Department of Animal and Environmental Biology, Delta State University, Abraka, Nigeria \\ ${ }^{3}$ National Mental Support Center for School Crisis, Osaka Kyoiku University, Osaka, Japan
}

\section{Email address:}

jcnmor@yahoo.com (J. C. Nmor)

\section{To cite this article:}

Judith Nmor, Kehi Harry Nwaka, Jephtha Christopher Nmor. Eating Behaviours of University Students in Southern Nigeria: An Evaluation of Sex Differences. Science Journal of Public Health. Vol. 2, No. 1, 2014, pp. 23-37. doi: 10.11648/j.sjph.20140201.14

\begin{abstract}
University students besides been the future nation builders, also represent the most viable population for education in the field of healthy lifestyles and eating habits. Although, eating habits are major determinate of health status, the eating habits of university students in Southern Nigeria has not been well documented. We aim to investigate their eating habits and sex difference with the view that our findings will be useful in developing adequate nutrition education. The participants, 108 students (48.2\% male and $51.9 \%$ female), aged $24.1 \pm 4.1$ filled out a self-reported questionnaire. Height and weight measurement were obtained. Eating habits, frequency of food intake, eating attitudes and fat-related dietary habits were reported. Our data showed that the majority of the students $(52.8 \%$ ) were of normal weight (male $51.9 \%$ compared to female $53.6 \%$ ). The overall prevalence of overweight (obese inclusive) was $40.4 \%$ for male and $35.7 \%$ for female. In terms of meal consumption frequency, students showed fairly good eating habits. There was no significant sex difference in the frequency of meal intake. Smoking was not common habit among students. Male students had significant lower means scores for modify meat to be low in fat and substitute high fat product with low fat. The correlation analysis of UPI subscale and eating attitude factors revealed some sex variations. For instance, eating attitude factors of F1 and F3 were positively associated with stress and dieting among male students but not for female students while UPI total, depression, anxiety and obsession was significantly related with hours of sleep per night for female but not for male students. Thus, patterns of association suggest a modulating effect of sex on eating behaviors. Efforts aimed at modifying unhealthy eating habits may benefit from a tailored approach, which takes into account individual differences in these factors.
\end{abstract}

Keywords: Eating Behavior, Body Mass Index, Sex-Differences, Fat-Related Habits, University Students, Nigeria

\section{Introduction}

Overweight and obesity are serious health problems. The prevalence of overweight and obesity has been escalating rapidly worldwide. Evidence suggests that the prevalence of overweight and obesity has reached global epidemic. It is now estimated that over one billion adults worldwide are overweight, about 500 million of them were obese [1].Eating practices have been identified as one of the factors fueling the global overweight and obesity epidemic. These include an increased consumption of energy dense foods that are high in fat and sugars but low in vitamins, minerals and other micronutrients as well as low consumption of legumes, milk, fruits and vegetables [2,3]. Also, Triches and Giugliani [4] reported that not eating breakfast in the morning gas well as a low frequency of milk, fruits and vegetables consumption, were practices associated with increased body weight and obesity among young people. In the same vein, lack of exercising and eating less than five servings of fruits and vegetables per day have been implicated as a risk factor for overweight [5].

Sex differences in food selection and intake appear in adolescence. Several studies have described remarkable differences in food choices between male and female. Consistently, female are more likely than male to have higher intakes of fruits and vegetables, higher intakes of dietary fibers and avoiding high-fat foods [6-8]. In accordance with such more healthy food choice, female usually attach greater importance to healthy eating. In addition, the motivation of weight control is more 
prominent in females and they are also more likely to be dieting. Female are more dissatisfied with their body weight and shape than male, and attached greater importance to healthy eating [8]. Given these sex-related differences in food selection, it is reasonable to hypothesize that there could be sex differences in other aspects of their eating behavior. This information is important to public health officials because better understanding of sex differences in eating habits could help create more targeted strategies for preventing unhealthy eating habits.

University students have been considered an important target for the promotion of healthy lifestyles of the adult population [9], and various studies have shown that there is a global increased attention on investigating the nutritional knowledge and eating habits indices of university students [10-14]. Gan et al. [15] highlighted the presence of unhealthy eating behaviors among university students and emphases the need to promote healthy eating habits among university students to achieve a healthy lifestyles.

Despite the growing global attention on the eating habits of university students, and the recognition of sex preferences in eating habits, reports on eating habits of university students in Southern Nigeria are scanty. Availability of information about these health-related factors are important for health educators and public health managers for designing and implementing health-related education programs that are geared towards healthy eating practices, especially as it relates to sex differences. Therefore, the purpose of this study was to evaluate the eating behavior of university students in Southern Nigeria and examine sex differences in eating habits. Information on sex differences could help guide health educators to target interventions more specifically.

\section{Methods}

\subsection{Participants and Ethical Consideration}

A total of 202 university students from Delta State University, Abraka voluntarily participated in the study. Of the 202 students, incomplete data were removed and 108 were included in the analysis. Of these, $48.2 \%$ were male while $51.9 \%$ were female. The average age of male participants was $24.7 \pm 4.5$ years while for female was 23.4 \pm 3.6 years. The average age of all participants was $24.1 \pm$ 4.0 years. The participants cut across various faculty and departments. Prior to the study, participants were pre informed of the significance of the research. A written consent was obtained from those who agreed to participate in the study. Ethical approval for the study was granted by the Human Research and Ethics Committee of University of Nagasaki. Permission to conduct the study at the Delta State University was granted by the Dean of student affairs.

\subsection{Anthropometric Assessment and Demographics}

A calibrated scale was used to determine weight. Individuals wore light clothing and no shoes and stood in the middle of the scale, without touching anything, and with their body equally distributed on both feet. Height measurements were taken with a secured graduated ruler. Measurement was taken at the standing height of participants, wearing light clothing and no shoes. Participants stood with their heels together, arms to the side, legs straight, and shoulders relaxed, and head in straight position. BMI was then used to assess students' weight status. Weight status was categorized into four: underweight (BMI $\leq 18.5$ ), normal weight (BMI between 18.5 and 24.9), overweight (BMI between 25.0 and 29.9) and obese (BMI $\geq 30$ ). In this study, the BMI classification of WHO was used (WHO, 1997). The sex and age were noted for all study participants.

\subsection{Study Design and Survey Instrument}

The study design was a cross-sectional survey conducted at the Delta State University Abraka campus during the first semester of 2012 Academic session. A self-administered questionnaire on eating habits which was adopted from previous published study $[14,16]$. The questionnaire consisted of different sections assessing the eating behaviors. Demographic data; such as age, sex, living arrangement etc. (1), present condition (2), present eating habits (3) were assessed with questions on frequency of use of fry pan or pot, and kitchen knife, daily meal frequency, meal frequently eaten and cooked. Eating attitudes (4), this section contained 36 items such as "I try to eat a wellbalanced diet," "I like to eat," "I worry about calorie when I eat" etc. (all items are shown in Table 6). The eating attitudes were assessed on a 4 point scale: (1) mostly does not apply, (2) rarely applies, (3) sometimes applies (4) fully applies [14].

Fat-related dietary habits were assessed using the FatRelated Dietary Habits Questionnaire (FDHQ). The use of FDHQ has been widely reported [17-19]. The FDHQ is a behavioral measure of dietary patterns related to selecting and preparing low-fat diets. The scoring system for FDHQ correlates positively with fat intake: higher scores correspond with higher fat intake [19]. Respondents in this study were asked to report their food choices over the past month. The items consisted of 25 items that were then combined into six subscale factors as follows: avoid frying; modify meats to be low in fat; substitute high fat products with low fat; replace meat; avoid fat as flavoring and replace high-fat foods with fruits and vegetables for dessert or snacks. Responses to the items were coded on a 4-point scale (usually or always, often, sometimes, rarely or never), and were scored 1 through 4 to correlate positively with fat intake for respective items on the questionnaire. Five items (fried chicken, fried fish, fried vegetable, fried potato/French fry, and eating vegetables with fat) were reversed-scored so that, a score of one would always reflect lower fat intake. Subscale scores were calculated as the mean of the subscale items. Finally, the University Personality Inventory (UPI), which is a questionnaire developed by the Japan University Health Association to 
evaluates the mental health of university students [20]. The UPI consists of 60 items and is designed to evaluate six subscales (lie, total, depression, anxiety, obsession and physical complaint). An affirmative response is scored as 1 point.

\subsection{Data Analysis}

The STATISTICA 06J software package (StatSoft Japan Co., Tokyo, Japan), and graph pad software, were used for data analysis. Cross-tabulations were performed to compare the responses of the students by sex. Chi-square tests were used to assess the statistical significance of the cross tabulation comparisons. Student $t$-test was used for parametric variables. Factor analyses were conducted for eating attitude using principal factor method with varimax rotation and correlation analysis was performed to examine the associations among weight and nutrition knowledge scores, eating attitude factor scores, fat subscale scores and UPI subscale scores. In the correlation analyses, only significant correlations $(P<0.05)$ above 0.2 of the absolute value are shown. All reported $P$ values were made on the basis of two-tailed tests. Differences were considered statistically significant at $P$ value $<0.05$.

\section{Results}

\subsection{Characteristics of Participants}

The characteristics of the participated students are presented in Table 1. The average BMI, hours of sleep per night and year of study at the university were $24.1 \pm 4.0$, $7.9 \pm 1.3$ hours and $3.4 \pm 1.2$ years respectively. Sex wise, males showed significantly higher weight and height than females. The BMI for male students (24.4) was slightly higher than females' (23.9); however there was no significant difference. The mean age and years of study was lower for female than males. Females had higher hours of sleep per night than males, though there was no significant difference.

Table 1. Characteristics of the participants (Mean $\pm S D)$ in relation to sex

\begin{tabular}{|c|c|c|c|c|}
\hline Variable & Total $(\mathrm{N}=108)$ & Male(N=52) & Female(N=56) & P value \\
\hline Age (years) & $24.1 \pm 4.0$ & $24.7 \pm 4.5$ & $23.4 \pm 3.6$ & 0.103 \\
\hline Weight(kg) & $69.5 \pm 13.5$ & $74.2 \pm 13.3$ & $65.1 \pm 12.7$ & 0.001 \\
\hline Height (cm) & $169.8 \pm 13.7$ & $174.6 \pm 11.1$ & $165.1 \pm 9.7$ & 0.001 \\
\hline Body mass index (BMI) & $24.1 \pm 4.2$ & $24.4 \pm 3.8$ & $23.9 \pm 4.5$ & 0.514 \\
\hline Hours of sleep/night & $7.9 \pm 1.3$ & $7.8 \pm 1.3$ & $8.1 \pm 1.3$ & 0.322 \\
\hline Mean years of study & $3.4 \pm 1.2$ & $3.6 \pm 1.3$ & $3.2 \pm 1.1$ & 0.312 \\
\hline
\end{tabular}

\subsection{Body Mass index (BMI) Distribution}

Table 2 presents the BMI distribution of the students. The data shows that only about half percent of the students $(52.8 \%)$ were of normal weight, $(52.9 \%$ of male students compared to $53.6 \%$ of female students). Based on BMI classification, the prevalence of overweight was higher among male students compared to female students $(40.4 \%$ vs. $35.7 \%$ ). In contrast, $10.7 \%$ of female students were underweight as compared to $9.3 \%$ of male students. Over all, there was no significant difference in the BMI status in relation to sex.

Table 2. Body mass index (BMI) distribution in relation to sex

\begin{tabular}{lccc}
\hline BMI & Total(N=108) & Male(N=52) & Female(N=56) \\
\hline Underweight (BMI $\leq 18.5)$ & $10(9.3)$ & $4(7.7)$ & $6(10.7)$ \\
Normal weight (BMI 18.5 - 24.9) & $57(52.8)$ & $27(51.9)$ & $30(53.6)$ \\
Overweight (BMI 25.0 $\geq 30.0$ ) & $41(40.0)$ & $21(40.4)$ & 0.597 \\
\hline
\end{tabular}

Data are presented in number and percent.*Obese inclusive

\subsection{Lifestyle of the Participants}

Table 3 presents some aspects of the lifestyle of the students. Data on the sleeping conditions shows that $30.4 \%$ of the female students always sleep well compared to $17.3 \%$ of the male students. Also, $40.4 \%$ of the males usually sleep well as against $37.5 \%$ of the female students. Only $32.7 \%$ of male students and $28.6 \%$ of the female students had an average sleeping condition. As few as $5.8 \%$ of males and $1.8 \%$ of females usually do not sleep well while $3.9 \%$ and $1.8 \%$ of male and female students respectively hardly ever sleep well. There was no significant sex difference in the sleeping conditions of the students. Reponses to the question on present health condition shows that $80.8 \%$ and $64.3 \%$ of male and female students respectively reported having a good health condition. Also, 33.9\% female students reported having a normal health compared to $19.2 \%$ of male students. Only about $1.8 \%$ of the female student reported having bad health condition. There was no statistical sex difference in the health status of the students. Table 3 also present the stress condition of the students. About half of both male and female students reported been under normal stress condition. Response to the smoking rate shows that $78.9 \%$ and $87.5 \%$ of male and female student respectively are none smokers. 
Table 3. Life style of participants presented in number and percent in relation to sex

\begin{tabular}{|c|c|c|c|c|c|}
\hline Questions & Answer level & $\begin{array}{l}\text { Total } \\
\text { Number (\%) } \\
(\mathrm{N}=108)\end{array}$ & $\begin{array}{l}\text { Male } \\
\text { Number (\%) } \\
(\mathrm{N}=52)\end{array}$ & $\begin{array}{l}\text { Female } \\
\text { Number (\%) } \\
(\mathrm{N}=56)\end{array}$ & $P$ value \\
\hline \multirow{5}{*}{$\begin{array}{l}\text { How well do } \\
\text { you sleep? }\end{array}$} & I hardly ever sleep well & $3(2.8)$ & $2(3.9)$ & $1(1.8)$ & \multirow[t]{5}{*}{0.451} \\
\hline & I usually do not sleep well & $4(3.7)$ & $3(5.8)$ & $1(1.8)$ & \\
\hline & Average & $33(30.6)$ & $17(32.7)$ & $16(28.6)$ & \\
\hline & I usually sleep well & $42(38.9)$ & 21(40.4) & $21(37.5)$ & \\
\hline & I always sleep well & $26(24.1)$ & $9(17.3)$ & $17(30.4)$ & \\
\hline \multirow{5}{*}{$\begin{array}{l}\text { How is your } \\
\text { present health } \\
\text { condition? }\end{array}$} & Very bad & $0(0.0)$ & $0(0.0)$ & $0(0.0)$ & \multirow[t]{5}{*}{0.248} \\
\hline & Bad & $1(0.9)$ & $0(0.0)$ & $1(1.8)$ & \\
\hline & Normal & $29(26.9)$ & $10(19.2)$ & 19(33.9) & \\
\hline & Good & $33(30.6)$ & $18(34.6)$ & $15(26.8)$ & \\
\hline & Very good & $45(41.7)$ & $24(46.2)$ & $21(37.5)$ & \\
\hline \multirow{5}{*}{$\begin{array}{l}\text { Do you feel } \\
\text { stressed lately? }\end{array}$} & Not at all & $17(15.7)$ & $7(13.5)$ & $10(17.9)$ & \multirow[t]{6}{*}{0.874} \\
\hline & Not really & $28(25.9)$ & $15(28.9)$ & $13(23.2)$ & \\
\hline & Normal & $55(50.9)$ & $26(50.0)$ & $29(51.8)$ & \\
\hline & Rather & $3(2.8)$ & $2(3.9)$ & $1(1.8)$ & \\
\hline & Very & $5(4.6)$ & $2(3.9)$ & $3(5.36)$ & \\
\hline \multirow{5}{*}{$\begin{array}{l}\text { How many } \\
\text { cigarettes do } \\
\text { you smoke per } \\
\text { day? }\end{array}$} & None & $90(83.3)$ & $41(78.9)$ & $49(87.5)$ & \\
\hline & $1-5$ & $12(11.1)$ & $7(13.5)$ & $5(8.9)$ & \multirow[t]{4}{*}{0.457} \\
\hline & $6-10$ & $6(5.6)$ & $4(7.7)$ & $2(3.6)$ & \\
\hline & $11-20$ & $0(0.0)$ & $0(0.0)$ & $0(0.0)$ & \\
\hline & More than 21 & $0(0.0)$ & $0(0.0)$ & $0(0.0)$ & \\
\hline \multirow{2}{*}{$\begin{array}{l}\text { Are you on a } \\
\text { diet? }\end{array}$} & Yes & 32 (29.6) & 15 (28.9) & $17(30.4)$ & \multirow[t]{2}{*}{0.863} \\
\hline & No & $76(70.4)$ & $37(71.2)$ & 39 (69.6) & \\
\hline
\end{tabular}

\subsection{The Frequency of Eating Daily Meal and Snacking in between Meals among the Students}

The percentages of participants who ate breakfast, lunch, and dinner every day and the percentages of those who ate snack in between meal are shown in Table 4. Only $69.2 \%$ and $64.3 \%$ of male and female students respectively ate breakfast. The percentage of students who reported eating lunch always was $55.8 \%$ and $58.9 \%$ for male and female students respectively. In terms of frequency of eating dinner, $80.8 \%$ male and $90.1 \%$ female students eats dinner always. Generally, the rate of meal skipping was low among the students and chi square test did not show any sex differences in the rate of daily meal consumption. Data on snacking rate between meals (Table 4 ) shows that $23.1 \%$ of male and $25.0 \%$ of female students always eat snack between meals while $61.5 \%$ male and $66.1 \%$ female reported that they sometimes do not eat snacks between meals. Although, there was no significant difference in the snacking rate between male and female students, females slightly snack more that male students. On the use of kitchen knives, $69.2 \%$ and $80.4 \%$ of males and female students respectively uses knife almost every day, while $57.7 \%$ and $76.8 \%$ of males and females respectively uses fry pan or pots almost every day. There was significant sex difference on the use of fry pan or pots among the students.

Table 4. Frequency of consumption of daily meals, snacking in between meals and the use of kitchen utensils in relation to sex

\begin{tabular}{|c|c|c|c|c|c|}
\hline Meals & Answer level & $\begin{array}{c}\text { Total } \\
\text { Number }(\%) \\
(\mathbf{N}=\mathbf{1 0 8}) \\
\end{array}$ & $\begin{array}{c}\text { Male } \\
\text { Number }(\%) \\
(\mathrm{N}=52)\end{array}$ & $\begin{array}{c}\text { Female } \\
\text { Number }(\%) \\
(\mathrm{N}=56)\end{array}$ & $P$ value \\
\hline \multirow{3}{*}{ Breakfast } & Always eat breakfast & $72(66.7)$ & $36(69.2)$ & $36(64.3)$ & 0.795 \\
\hline & Sometimes do not eat breakfast & $33(30.6)$ & $15(28.9)$ & $18(32.1)$ & \\
\hline & Mostly do not eat breakfast & $3(2.8)$ & $1(1.9)$ & $2(3.6)$ & \\
\hline \multirow{4}{*}{ Lunch } & Always eat lunch & $62(57.4)$ & $29(55.8)$ & $33(58.9)$ & 0.531 \\
\hline & Sometimes do not eat lunch & $44(40.7)$ & $21(40.4)$ & $23(41.1)$ & \\
\hline & Mostly do not eat lunch & $1(0.9)$ & $1(1.9)$ & $0(0.0)$ & \\
\hline & Never eat lunch & $1(0.9)$ & $1(1.9)$ & $0(0.0)$ & \\
\hline
\end{tabular}




\begin{tabular}{|c|c|c|c|c|c|}
\hline Meals & Answer level & $\begin{array}{c}\text { Total } \\
\text { Number }(\%) \\
(\mathrm{N}=108) \\
\end{array}$ & $\begin{array}{c}\text { Male } \\
\text { Number (\%) } \\
(\mathrm{N}=52)\end{array}$ & $\begin{array}{c}\text { Female } \\
\text { Number }(\%) \\
(\mathrm{N}=56)\end{array}$ & $P$ value \\
\hline \multirow{2}{*}{ Dinner } & Always eat dinner & $93(86.1)$ & $42(80.8)$ & $51(91.1)$ & 0.122 \\
\hline & Sometimes do not eat dinner & $15(13.9)$ & $10(19.2)$ & $5(8.9)$ & \\
\hline \multirow{4}{*}{$\begin{array}{l}\text { Snack in } \\
\text { between } \\
\text { meals }\end{array}$} & Always eat snacks between meals & $26(24.1)$ & $12(23.1)$ & $14(25.0)$ & 0.364 \\
\hline & Sometimes do not eat snacks between meals & $69(63.9)$ & $32(61.5)$ & $37(66.1)$ & \\
\hline & Mostly do not eat snacks between meals & $7(6.5)$ & $3(5.8)$ & $4(7.1)$ & \\
\hline & Never eat snacks between meals & $6(5.6)$ & $5(9.6)$ & $1(1.8)$ & \\
\hline \multirow{4}{*}{ Use of: Knife } & Almost every day & $81(75.0)$ & $36(69.2)$ & $45(80.4)$ & 0.125 \\
\hline & 3-4 times a week & $14(13.0)$ & $6(11.5)$ & $8(14.3)$ & \\
\hline & 1-2 times a week & $10(9.3)$ & $7(13.5)$ & $3(5.4)$ & \\
\hline & Almost never & $3(2.8)$ & $3(5.8)$ & $0(0.0)$ & \\
\hline \multirow{4}{*}{ Fry pan or pot } & Almost every day & $73(67.6)$ & $30(57.7)$ & $43(76.8)$ & 0.032 \\
\hline & 3-4 times a week & $17(15.7)$ & $8(15.4)$ & $9(16.1)$ & \\
\hline & 1-2 times a week & $14(13.0)$ & $10(19.2)$ & $4(7.2)$ & \\
\hline & Almost never & $4(3.7)$ & $4(7.7)$ & $0(0.0)$ & \\
\hline
\end{tabular}

\subsection{Nutrition Knowledge}

The items surveying nutrition knowledge were evaluated and the percentage correctly answered was compared between sexes (Table 5). There was a significant sex difference in only on one item: (Vitamins are a good source of energy), with $9.6 \%$ of the males students correctly answered this item as compared to $30.4 \%$ of female students. The percentage correct ratio for male and female were $46.5 \%$ and $47.1 \%$ respectively, and no significant difference was found between sexes.

\subsection{Eating Attitudes}

The 36 items surveying eating attitudes were evaluated and the means were compared between sexes. The results of these analyses are shown in Table 6. Although, female students had relatively higher mean scores for most of the items, there was no clear pattern in the means scores. Significant sex differences were observed in only three items $(10,15$ and 22). The highest mean scores for male students were found on items 31,19 and 36, while for female counterpart, items $1,8,21$ and 36 had the highest mean scores. More so, for male students, item 22 had the least mean score while for female item 34 showed the least score.

Table 5.Percentage of students who correctly answered questions on general nutrition knowledge in relation to sex

\begin{tabular}{|c|c|c|c|c|c|}
\hline & Items & $\begin{array}{l}\text { Total } \\
(\mathbf{N}=\mathbf{1 0 8})\end{array}$ & $\begin{array}{l}\text { Male } \\
(\mathrm{N}=\mathbf{5 2})\end{array}$ & $\begin{array}{l}\text { Female } \\
(\mathrm{N}=56)\end{array}$ & $P$ value \\
\hline 1. & When we eat, insulin is released. & 60.2 & 65.4 & 55.4 & 0.288 \\
\hline 2. & Vitamins are a good source of energy. & 20.4 & 9.6 & 30.4 & $0.008 *$ \\
\hline 3. & Human body consists of water to an extent of about $50 \%$. & 37.0 & 34.6 & 39.3 & 0.616 \\
\hline 4. & Calcium can be found in great amounts in vegetables, potatoes, and fruits. & 18.5 & 19.2 & 17.9 & 0.854 \\
\hline 5. & $\begin{array}{l}\text { The same amount of carbohydrates and proteins contain the same amount of } \\
\text { calories. }\end{array}$ & 15.7 & 19.2 & 12.5 & 0.337 \\
\hline 6. & Unsaturated fatty acid is not found in beef and pork. & 93.5 & 94.2 & 92.9 & 0.772 \\
\hline 7. & Food poisoning is caused by overeating. & 71.3 & 73.1 & 69.6 & 0.694 \\
\hline 8. & Carrots are a good source of Vitamin A. & 38.9 & 38.5 & 39.3 & 0.930 \\
\hline 9. & Carbohydrates, like proteins and fat, are not easily digested. & 47.2 & 42.3 & 51.8 & 0.324 \\
\hline 10 . & The absorption of nutrients in spinach is better when it is fried in oil. & 13.9 & 13.5 & 14.3 & 0.902 \\
\hline 11. & Bread and Cereals are both sources of dietary fiber. & 63.0 & 67.3 & 58.9 & 0.368 \\
\hline 12. & $\begin{array}{l}\text { Deep-fried food is ready in a short amount of time, but many nutrients get lost } \\
\text { during the process. }\end{array}$ & 42.6 & 50.0 & 35.7 & 0.134 \\
\hline 13. & Even during a diet, the intake of fat is necessary to a certain extent. & 66.7 & 65.4 & 67.9 & 0.785 \\
\hline 14. & Animal foods do not contain dietary fibers. & 26.9 & 23.1 & 30.4 & 0.394 \\
\hline 15. & The amount of calories in $1 \mathrm{~g}$ of alcohol is higher than that of proteins. & 20.4 & 21.2 & 19.6 & 0.846 \\
\hline 16. & There are many proteins in apples. & 75.0 & 71.2 & 78.6 & 0.374 \\
\hline 17. & A balanced meal is a meal with a low intake of fat. & 24.1 & 21.2 & 26.8 & 0.494 \\
\hline 18. & Minerals are nutrients that improve your health & 80.6 & 80.8 & 80.4 & 0.957 \\
\hline 19. & $\begin{array}{l}\text { Genetically modified food is food that contains genetic material other than that } \\
\text { originally found in that type of food. }\end{array}$ & 32.4 & 36.5 & 28.6 & 0.377 \\
\hline \multirow[t]{2}{*}{20.} & $\begin{array}{l}\text { Of the three diseases Hepatitis A, pneumonia, and influenza, the following } \\
\text { disease is transmitted by eating contaminated food: pneumonia. }\end{array}$ & 88.9 & 84.6 & 92.9 & 0.288 \\
\hline & Total correct ratio & 46.9 & 46.5 & 47.1 & 0.942 \\
\hline
\end{tabular}

*Indicates significant difference at $P<0.05$. 
Table 6.Item means for eating attitudes in relation to sex

\begin{tabular}{|c|c|c|c|c|c|}
\hline & Items & $\begin{array}{l}\text { Total } \\
(\mathrm{N}=108)\end{array}$ & $\begin{array}{l}\text { Male } \\
(\mathrm{N}=52)\end{array}$ & $\begin{array}{l}\text { Female } \\
(N=56)\end{array}$ & $\begin{array}{l}P \\
\text { value }\end{array}$ \\
\hline 1 & I try to eat a well-balanced diet. & 3.29 & 3.23 & 3.34 & 0.528 \\
\hline 2 & I seriously would like to learn cooking. & 3.00 & 2.94 & 3.05 & 0.578 \\
\hline 3 & I check for food additives, food coloring, etc. in my food. & 2.62 & 2.50 & 2.73 & 0.239 \\
\hline 4 & I eat precooked food, instant and frozen products, and delivery foods (e.g.,pizza). & 2.48 & 2.54 & 2.43 & 0.514 \\
\hline 5 & I take nutritional supplements like vitamin tablets or similar products. & 2.74 & 2.81 & 2.68 & 0.474 \\
\hline 6 & The amount of my food intake varies depending on my mood. & 2.95 & 2.83 & 3.07 & 0.108 \\
\hline 7 & Practicing healthy eating behavior is important to me. & 3.18 & 3.19 & 3.16 & 0.842 \\
\hline 8 & I would like people to commend my cooking. & 3.07 & 2.94 & 3.20 & 0.121 \\
\hline 9 & I buy natural foods and organic vegetables even if they cost more. & 2.80 & 2.64 & 2.95 & 0.050 \\
\hline 10 & I try not to eat too much. & 2.93 & 2.75 & 3.09 & $0.019 *$ \\
\hline 11 & Fast food is delicious and convenient. & 2.74 & 2.60 & 2.88 & 0.062 \\
\hline 12 & I highly value pre-cooked dishes in the supermarket. & 2.40 & 2.37 & 2.43 & 0.728 \\
\hline 13 & I try to eat slowly and chew well. & 3.07 & 3.06 & 3.09 & 0.835 \\
\hline 14 & I like to change the dishes I use depending on my mood. & 2.94 & 2.85 & 3.02 & 0.350 \\
\hline 15 & I feel uneasy about trusting imported foods. & 2.69 & 2.48 & 2.89 & $0.018^{*}$ \\
\hline 16 & I want to save money on food and spend it on other things & 1.95 & 1.85 & 2.05 & 0.301 \\
\hline 17 & I try to eat a variety of foods. & 3.05 & 3.08 & 3.02 & 0.704 \\
\hline 18 & I try to eat at the same time every day. & 2.52 & 2.40 & 2.63 & 0.199 \\
\hline 19 & I try to enjoy eating my meals. & 3.20 & 3.27 & 3.14 & 0.404 \\
\hline 20 & I think there are many tasty instant noodle soups. & 2.56 & 2.58 & 2.54 & 0.817 \\
\hline 21 & I would like to know more about food nutrients and what functions they have. & 3.19 & 3.17 & 3.20 & 0.875 \\
\hline 22 & I don't care what I eat as long as it fills my stomach. & 1.90 & 1.69 & 2.09 & $0.039 *$ \\
\hline 23 & I want to buy and try out new food products as soon as they are released. & 2.69 & 2.67 & 2.71 & 0.771 \\
\hline 24 & I want to lose weight just by eating a well-balanced diet. & 2.59 & 2.54 & 2.64 & 0.581 \\
\hline 25 & I always drink vitamin drinks. & 2.87 & 2.73 & 3.00 & 0.084 \\
\hline 26 & I don't mind eating the same things every day. & 2.41 & 2.33 & 2.48 & 0.377 \\
\hline 27 & I only want to eat my favorite dishes. & 2.81 & 2.77 & 2.84 & 0.648 \\
\hline 28 & I dislike cooking and cleaning up afterwards. & 2.31 & 2.29 & 2.34 & 0.792 \\
\hline 29 & When food tastes good, I eat more than usual. & 3.10 & 3.02 & 3.18 & 0.315 \\
\hline 30 & I worry about calories when eating. & 2.66 & 2.64 & 2.68 & 0.770 \\
\hline 31 & My eating habits are normal. & 3.21 & 3.33 & 3.11 & 0.147 \\
\hline 32 & It's OK not to eat. & 2.53 & 2.44 & 2.61 & 0.361 \\
\hline 33 & I like to eat. & 3.19 & 3.23 & 3.14 & 0.591 \\
\hline 34 & I feel like eating when I am in a bad mood. & 2.05 & 2.14 & 1.96 & 0.400 \\
\hline 35 & When I see a person eating, I want to eat as well. & 2.51 & 2.56 & 2.46 & 0.658 \\
\hline 36 & I like to strengthen relationships with others by eating together. & 3.23 & 3.27 & 3.20 & 0.677 \\
\hline
\end{tabular}

The items were rated on a 4 point scale: (1) mostly does not apply, (2) rarely applies, (3) sometimes applies (4) fully applies. *Indicates significant difference at $P<0.05$.

\subsection{Factor Analysis of Eating Attitudes}

Factor analysis of the eating attitudes questionnaire was performed by principal factor method. Items with factor loadings under 0.4 were removed from the model. The final outcome of the factor analysis loaded onto three(Table7). The first factor (F1), [items 7, 13, 19, 31, 29, 21, 33, 17 and 25; alpha coefficient 0.866 ] was named "healthy eating habits" because its constituent items were related to attitudes reflecting healthy eating behaviors. The second factor (F2),[items 35, 12, 4, 18, 27, 34, 24, and 30; alpha coefficient 0.809 ] was named "emotional and personal eating style" because the items relates to emotions and personal eating attitudes. The third factor (F3), [items 6, 4, 27, and 5; alpha coefficient 0.665] was called "consciousness in food safety" and included items about eating carefulness. The cumulative contribution ratio was $42.5 \%$, and the individual contribution ratios of F1, F2 and F3 were20.0, 15.0and 7.5\%, respectively. 
Table 7.Main factor structures derived from the factor analysis ${ }^{a)}$

\begin{tabular}{|c|c|c|c|}
\hline \multirow{2}{*}{ Factors } & \multicolumn{3}{|c|}{ Factor loading } \\
\hline & F1 & F2 & F3 \\
\hline \multicolumn{4}{|l|}{ F1: Healthy eating habits $(\alpha=0.866)$} \\
\hline 7. Practicing healthy eating behavior is important to me. & 0.838 & -0.061 & 0.057 \\
\hline 13. I try to eat slowly and chew well. & 0.721 & -0.087 & 0.532 \\
\hline 19. I try to enjoy eating my meals. & 0.718 & 0.058 & 0.137 \\
\hline 31. My eating habits are normal. & 0.663 & 0.008 & 0.113 \\
\hline 29. When food tastes good, I eat more than usual. & 0.617 & 0.212 & -0.045 \\
\hline 21. I would like to know more about food nutrients and what functions they have. & 0.614 & -0.248 & 0.075 \\
\hline 33. I like to eat. & 0.608 & 0.130 & -0.197 \\
\hline 17. I try to eat a variety of foods. & 0.607 & 0.020 & 0.148 \\
\hline 25. I always drink vitamin drinks. & 0.510 & 0.245 & 0.041 \\
\hline \multicolumn{4}{|l|}{ F2: Emotional and personal eating style $(\alpha=0.809)$. } \\
\hline 35. When I see a person eating, I want to eat as well. & 0.021 & 0.767 & 0.124 \\
\hline 12. I highly value pre-cooked dishes in the supermarket. & -0.087 & 0.753 & 0.016 \\
\hline 4. I eat precooked food, instant and frozen products, and delivery foods (e.g., pizza). & 0.162 & 0.652 & 0.040 \\
\hline 18. I try to eat at the same time every day. & -0.024 & 0.598 & 0.285 \\
\hline 27. I only want to eat my favorite dishes. & 0.157 & 0.533 & -0.045 \\
\hline 34. I feel like eating when I am in a bad mood. & -0.292 & 0.528 & 0.255 \\
\hline 24. I want to lose weight just by eating a well-balanced diet. & 0.199 & 0.482 & -0.016 \\
\hline 30. I worry about calories when eating. & 0.172 & 0.464 & -0.038 \\
\hline \multicolumn{4}{|l|}{ F3:Consciousness in food safety $(\alpha=0.665)$} \\
\hline 14. I like to change the dishes I use depending on my mood. & 0.259 & 0.037 & 0.619 \\
\hline 9. I buy natural foods and organic vegetables even if they cost more. & 0.332 & 0.167 & 0.531 \\
\hline 1. I try to eat a well-balanced diet. & 0.216 & 0.114 & 0.500 \\
\hline 3. I check for food additives, food coloring, etc. in my food. & 0.223 & -0.075 & 0.475 \\
\hline 15. I feel uneasy about trusting imported foods. & 0.198 & 0.137 & 0.435 \\
\hline Contribution $(\%)$ & 20.0 & 15.0 & 7.5 \\
\hline
\end{tabular}

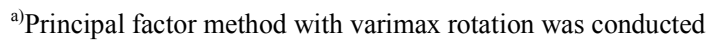

The mean factor scores are shown in Table 8 . There were no significant sex differences except for F3. The mean score for F3 was higher for female students compared to male students.

Table 8. The mean scores of eating attitudes factor scores in relation to sex

\begin{tabular}{lllll}
\hline $\begin{array}{l}\text { Eating attitudes } \\
\text { factor scores }\end{array}$ & $\begin{array}{l}\text { Total } \\
(\mathbf{N = 1 0 8})\end{array}$ & $\begin{array}{l}\text { Male } \\
(\mathbf{N = 5 2})\end{array}$ & $\begin{array}{l}\text { Female } \\
(\mathbf{N = 5 6 )}\end{array}$ & $\begin{array}{l}\boldsymbol{P} \\
\text { value }\end{array}$ \\
\hline $\begin{array}{l}\text { F1 (Healthy eating } \\
\text { habits) }\end{array}$ & $28.06 \pm 5.0$ & $28.08 \pm 4.6$ & $28.04 \pm 5.4$ & 0.966 \\
$\begin{array}{l}\text { F2 (Emotional and } \\
\text { personal eating style) }\end{array}$ & $23.01 \pm 5.1$ & $22.88 \pm 5.0$ & $23.13 \pm 5.2$ & 0.807 \\
$\begin{array}{l}\text { F3 (Consciousness in } \\
\text { food safety) }\end{array}$ & $14.33 \pm 3.0$ & $13.69 \pm 3.1$ & $14.93 \pm 2.8$ & 0.032 \\
\hline
\end{tabular}

\subsection{Fat-Related Dietary Habits Questionnaire (FDHQ) Subscale Scores}

Table 9. The mean scores for FDHQ subscales in relation to sex

\begin{tabular}{|c|c|c|c|c|}
\hline FDHQ subscales & $\begin{array}{c}\text { Total } \\
(\mathrm{N}=108)\end{array}$ & $\begin{array}{c}\text { Male } \\
(\mathrm{N}=\mathbf{5 2})\end{array}$ & $\begin{array}{l}\text { Female } \\
(\mathrm{N}=56)\end{array}$ & $P$ value \\
\hline Avoid frying & $9.27 \pm 2.96$ & $8.79 \pm 3.24$ & $9.71 \pm 2.63$ & 0.105 \\
\hline Modify meat to be low in fat & $6.91 \pm 2.93$ & $6.33 \pm 3.15$ & $7.45 \pm 2.62$ & 0.047 \\
\hline Substitute high fat products with low fat & $16.4 \pm 5.80$ & $14.65 \pm 6.99$ & $18.04 \pm 3.81$ & 0.002 \\
\hline Replace meats & $2.17 \pm 1.31$ & $1.98 \pm 1.39$ & $2.34 \pm 1.21$ & 0.156 \\
\hline Avoid fat as flavoring & $12.2 \pm 3.5$ & $11.71 \pm 4.18$ & $12.70 \pm 2.67$ & 0.145 \\
\hline $\begin{array}{l}\text { Replace high fat food with fruits and } \\
\text { vegetables }\end{array}$ & $12.1 \pm 3.27$ & $11.67 \pm 3.69$ & $12.54 \pm 2.81$ & 0.173 \\
\hline
\end{tabular}

Table 9 summarizes the mean scores for FDHQ subscales in relation to sex. Lower scores indicate that fatlowering behaviors are being practiced more frequently. Male student had a significantly lower mean score for modify meat to be low in fat (6.33) compare to the female counterparts (7.45). The mean score for substitute high fat products with low fat was also significantly lower among male students (14.65) compared to female students (18.04). Replace meats remained the lowest mean score for both male and female student, though there was no significant sex difference. Male students consistently had lower mean scores for all FDHQ subscales compared to female students; there was no significant differences with respect to sex except for modify meat to be low in fat and substitute high fat products with low fat. 


\subsection{Degree of Mental Health Using the University Personality Inventory (UPI)}

Evaluation of degree of mental health of university students was done using the university personality inventory (UPI). The responses to these items are presented in percentages of students affirming to the items(Table 10). Of the 60 items only6 items $(1,12,15,16,29$ and 41) showed significant sex differences. The highest checked ratio for male students were found on items $57,53,5$ and 20, while for female counterpart, items 53, 57, 5 and 20.

Table 10.Check ratio (\%) of each UPI item in relation to sex

\begin{tabular}{|c|c|c|c|c|c|}
\hline & Items & $\begin{array}{l}\text { Total } \\
(N=108)\end{array}$ & $\begin{array}{l}\text { Male } \\
(\mathrm{N}=52)\end{array}$ & $\begin{array}{l}\text { Female } \\
(\mathrm{N}=56)\end{array}$ & $P$ value \\
\hline 1 & I have a poor appetite. & 28.7 & 17.3 & 39.3 & 0.012 \\
\hline 2 & I sometimes suffer from nausea, heartburn, or stomach pains. & 38.9 & 36.5 & 41.1 & 0.629 \\
\hline 3 & Without reason, I suffer from constipation or diarrhea. & 41.7 & 44.2 & 39.3 & 0.603 \\
\hline 4 & I am troubled by a fast, or irregular, heart-beat. & 11.1 & 7.7 & 14.3 & 0.276 \\
\hline 5 & I am in top physical condition. & 58.3 & 61.5 & 55.4 & 0.515 \\
\hline 6 & I am bugged by many things and complain much. & 13.0 & 9.6 & 16.1 & 0.318 \\
\hline 7 & My parents expect far too much of me. & 27.8 & 32.7 & 23.2 & 0.272 \\
\hline 8 & I have had an unhappy family life. & 6.5 & 9.6 & 3.6 & 0.202 \\
\hline 9 & I am overly anxious about the future. & 25.0 & 28.9 & 21.4 & 0.374 \\
\hline 10 & I prefer not to meet people. & 3.7 & 1.9 & 5.4 & 0.345 \\
\hline 11 & I feel that I am not my own person. & 5.6 & 9.6 & 1.8 & 0.076 \\
\hline 12 & I am unmotivated. & 7.4 & 9.6 & 5.4 & 0.040 \\
\hline 13 & I am inclined to be pessimistic. & 9.3 & 13.5 & 5.4 & 0.147 \\
\hline 14 & I find it difficult to think clearly. & 4.6 & 5.8 & 3.6 & 0.587 \\
\hline 15 & I am overly moody. & 7.4 & 1.9 & 12.5 & 0.036 \\
\hline 16 & I frequently find it difficult to sleep. & 6.5 & 11.5 & 1.8 & 0.040 \\
\hline 17 & I suffer from headaches. & 26.9 & 25.0 & 28.6 & 0.676 \\
\hline 18 & I feel stiff around my shoulders and neck. & 19.4 & 25.0 & 14.3 & 0.160 \\
\hline 19 & I suffer from chest pains, or tightness in the chest. & 15.7 & 13.5 & 17.9 & 0.531 \\
\hline 20 & I always participate actively in things. & 44.4 & 46.2 & 42.9 & 0.731 \\
\hline 21 & I am overly timid. & 4.6 & 5.8 & 3.6 & 0.587 \\
\hline 22 & I am overly anxious about many things. & 29.6 & 32.7 & 26.8 & 0.502 \\
\hline 23 & I become easily irritated. & 22.2 & 17.3 & 26.8 & 0.237 \\
\hline 24 & I am quick-tempered. & 15.7 & 15.4 & 16.1 & 0.922 \\
\hline 25 & I sometimes wish I was dead. & 0.9 & 1.9 & 0.0 & 0.297 \\
\hline 26 & I feel indifferent towards everything. & 5.6 & 7.7 & 3.6 & 0.350 \\
\hline 27 & My memory is getting worse. & 1.9 & 3.9 & 0.0 & 0.139 \\
\hline 28 & I do not finish things that I begin. & 4.6 & 3.9 & 5.4 & 0.709 \\
\hline 29 & I lack decisiveness. & 4.6 & 9.6 & 0.0 & 0.018 \\
\hline 30 & I am overly dependent on others. & 1.9 & 3.9 & 0.0 & 0.139 \\
\hline 31 & I find myself blushing easily. & 2.8 & 5.8 & 0.0 & 0.068 \\
\hline 32 & I am inclined to stutter. & 7.4 & 11.5 & 3.6 & 0.114 \\
\hline 33 & I sometimes get hot flashes or cold chills. & 7.4 & 5.8 & 8.9 & 0.531 \\
\hline 34 & I have an emotional problem with my urination and/or genitals. & 3.7 & 3.9 & 3.6 & 0.940 \\
\hline 35 & I am a light-hearted person. & 21.3 & 23.1 & 19.6 & 0.663 \\
\hline 36 & One way or the other, I am always fearful. & 12.0 & 7.7 & 16.1 & 0.181 \\
\hline 37 & When I'm alone, I cannot relax. & 9.3 & 9.6 & 8.9 & 0.902 \\
\hline 38 & I lack confidence. & 8.3 & 5.8 & 10.7 & 0.353 \\
\hline 39 & I tend to be hesitant about everything. & 14.8 & 11.5 & 17.9 & 0.356 \\
\hline
\end{tabular}




\begin{tabular}{|c|c|c|c|c|c|}
\hline & Items & $\begin{array}{l}\text { Total } \\
(\mathrm{N}=108)\end{array}$ & $\begin{array}{l}\text { Male } \\
(\mathrm{N}=52)\end{array}$ & $\begin{array}{l}\text { Female } \\
(\mathrm{N}=56)\end{array}$ & $P$ value \\
\hline 40 & I am frequently judged wrongly by others. & 21.3 & 23.1 & 19.6 & 0.663 \\
\hline 41 & I cannot trust other people. & 28.7 & 19.2 & 37.5 & 0.036 \\
\hline 42 & I am overly suspicious. & 13.9 & 11.5 & 16.1 & 0.496 \\
\hline 43 & I am not a sociable person. & 12.0 & 5.8 & 17.9 & 0.054 \\
\hline 44 & I feel inferior to others. & 1.9 & 1.9 & 1.8 & 0.958 \\
\hline 45 & I worry unduly about the future. & 6.5 & 5.8 & 7.1 & 0.772 \\
\hline 46 & My body feels heavy. & 13.0 & 9.6 & 16.1 & 0.318 \\
\hline 47 & When I am anxious, I easily get into a cold sweat. & 10.2 & 5.8 & 14.3 & 0.144 \\
\hline 48 & I have dizzy spells. & 2.8 & 3.9 & 1.8 & 0.515 \\
\hline 49 & I faint and have convulsions. & 0.0 & 0.0 & 0.0 & - \\
\hline 50 & I am usually liked by others. & 44.4 & 40.4 & 48.2 & 0.413 \\
\hline 51 & I am overly pedantic. & 1.9 & 3.9 & 0.0 & 0.139 \\
\hline 52 & I need to check things repeatedly. & 24.1 & 26.9 & 21.4 & 0.505 \\
\hline 53 & I am overly sensitive about dirt. & 66.7 & 63.5 & 69.6 & 0.496 \\
\hline 54 & I can't rid myself of unrelated thoughts. & 7.4 & 7.7 & 7.1 & 0.913 \\
\hline 55 & I worry about my own body odor. & 9.3 & 9.6 & 8.9 & 0.902 \\
\hline 56 & People talk about me behind my back. & 21.3 & 17.3 & 25.0 & 0.329 \\
\hline 57 & I am overly anxious about the people around me. & 62.0 & 65.4 & 58.9 & 0.490 \\
\hline 58 & I am bothered by people looking at me. & 13.9 & 15.4 & 12.5 & 0.665 \\
\hline 59 & People pay no attention to me. & 2.8 & 5.8 & 0.0 & 0.683 \\
\hline 60 & I am easily hurt by others. & 15.7 & 11.5 & 19.6 & 0.248 \\
\hline
\end{tabular}

Table 11.The mean scores of subscales of UPI in relation to sex

\begin{tabular}{lcccc}
\hline Subscales of UPI & $\begin{array}{c}\text { Total } \\
(\mathbf{N = 1 0 8})\end{array}$ & $\begin{array}{c}\text { Male } \\
\text { (N=52) }\end{array}$ & $\begin{array}{c}\text { Female } \\
\text { (N=56) }\end{array}$ & $\begin{array}{c}\boldsymbol{P} \text { value } \\
\text { Lie }\end{array}$ \\
Total & $1.69 \pm 1.05$ & $1.71 \pm 1.13$ & $1.66 \pm 0.98$ & 0.802 \\
Depression & $7.92 \pm 5.09$ & $7.81 \pm 5.84$ & $8.02 \pm 4.33$ & 0.831 \\
Anxiety & $2.02 \pm 2.25$ & $2.25 \pm 2.51$ & $1.80 \pm 1.98$ & 0.305 \\
Obsession & $1.29 \pm 1.47$ & $1.02 \pm 1.38$ & $1.54 \pm 1.53$ & 0.068 \\
Physical complaint & $2.25 \pm 1.36$ & $2.27 \pm 1.48$ & $2.23 \pm 1.25$ & 0.888 \\
\hline
\end{tabular}

\subsection{Subscales of UPI}

Table 11 shows the mean scores for UPI subscales for the participated students. Higher UPI subscale scores mean lower mental health states except for lie scale. The mean score for depression was 2.25 and 1.80 for male and female students respectively. While the mean score for anxiety was 1.02 and 1.54 for male and female students respectively. There were no significant sex differences in all UPI subscales.

\subsection{Associations between Eating Attitudes, Mental Health, FDHQ Subscale Scores and Eating Behaviors}

The correlation coefficients for the association between eating attitudes factor scores, UPI subscale scores, FDHQ subscale scores and eating behavior were investigated for male (Table 12), and for female ( Table 13). The correlation analyses showed variation in the pattern of association of the variables with respect to sex. For male, the pattern of association showed that eating attitudes factor score was positively related to life style but negatively associated with frequency of snacking between meals. Also UPI subscale showed significant correlation with eating attitudes factor score F2. FDHQ subscales showed negative association with frequency of snacking between meals and positive association with eating attitudes factor scores F2 and F3(Table 12). 
Table 12. The associations between eating attitudes factor scores, UPI subscale scores, FDHQ subscale scores and eating behavior for male(N=52). Only significant correlations $(P<0.05)$ above 0.2 of the absolute value are shown.

\begin{tabular}{|c|c|c|c|c|c|c|c|c|c|c|c|c|c|c|c|c|}
\hline & BMI & $\begin{array}{l}\text { Hours } \\
\text { of } \\
\text { Sleep } \\
\text { /night }\end{array}$ & $\begin{array}{l}\text { Sleep } \\
\text { con- } \\
\text { dition }\end{array}$ & $\begin{array}{l}\text { Health } \\
\text { status }\end{array}$ & $\begin{array}{l}\text { Stress } \\
\text { status }\end{array}$ & $\begin{array}{l}\text { Ciga } \\
\text { smok- } \\
\text { ing }\end{array}$ & $\begin{array}{l}\text { Diet- } \\
\text { ing }\end{array}$ & $\begin{array}{l}\text { Use } \\
\text { of } \\
\text { knife }\end{array}$ & $\begin{array}{l}\text { Use } \\
\text { of } \\
\text { fry } \\
\text { pan }\end{array}$ & $\begin{array}{l}\text { Break } \\
\text { fast } \\
\text { freq }\end{array}$ & $\begin{array}{l}\text { Lunch } \\
\text { freq }\end{array}$ & $\begin{array}{l}\text { Dinner } \\
\text { freq }\end{array}$ & $\begin{array}{l}\text { Snack } \\
\text { btw } \\
\text { meal }\end{array}$ & $\mathrm{F} 1$ & F2 & F3 \\
\hline $\mathrm{F} 1$ & & & & & 0.31 & & & & & & & & & & & \\
\hline $\mathrm{F} 2$ & & & & & & & & & 0.32 & & & & -0.39 & & & \\
\hline F3 & & & & & 0.33 & & 0.35 & & & & & & -0.30 & & & \\
\hline Lie & & & & & & & & & & 0.37 & & & & & & \\
\hline Total & & & & & & & & & & & & & & & 0.33 & \\
\hline Depression & & & & & & & & & & & & & 0.33 & & & \\
\hline Anxiety & & & -0.32 & & & & & & & & & & & & & \\
\hline Obsession & & & & & & & & & & & & & & & 0.36 & \\
\hline Phy com & & & & & & & & & & & & & & & 0.30 & \\
\hline Nut know & & & & & 0.34 & & & & & & & & & & 0.39 & 0.33 \\
\hline $\begin{array}{l}\text { Avoid } \\
\text { frying }\end{array}$ & & & & & & & & $-\overline{0.28}$ & & & & & & & & 0.33 \\
\hline $\begin{array}{l}\text { Modify } \\
\text { meat }\end{array}$ & & & & & & & & & & & & & -0.35 & & & 0.37 \\
\hline $\begin{array}{l}\text { Sub high } \\
\text { fat }\end{array}$ & & & & & & & & & & & & & -0.33 & & 0.35 & 0.48 \\
\hline $\begin{array}{l}\text { Replace } \\
\text { meat }\end{array}$ & & & & & & & & & & & & & -0.37 & & 0.40 & 0.37 \\
\hline $\begin{array}{l}\text { Avoid fat } \\
\text { as } \\
\text { flavoring }\end{array}$ & & & & & & & & & & & & & -0.32 & & 0.32 & 0.47 \\
\hline $\begin{array}{l}\text { Replace } \\
\text { with fruits } \\
\& \text { veg }\end{array}$ & & & & & & & 0.38 & & & & & & -0.29 & & 0.36 & 0.51 \\
\hline
\end{tabular}

Ciga(cigarette), freq(frequency), bwt (between), F1(healthy eating habits), F2(emotional and personal eating style), F3(consciousness in food safety),Phy com (physical complaint), Nut know(nutrition knowledge), sub(substitute), veg (vegetable).

Table 13. The associations between eating attitudes factor scores, UPI subscale scores, FDHQ subscale scores and eating behavior for female(N=56). Only significant correlations $(P<0.05)$ above 0.2 of the absolute value are shown.

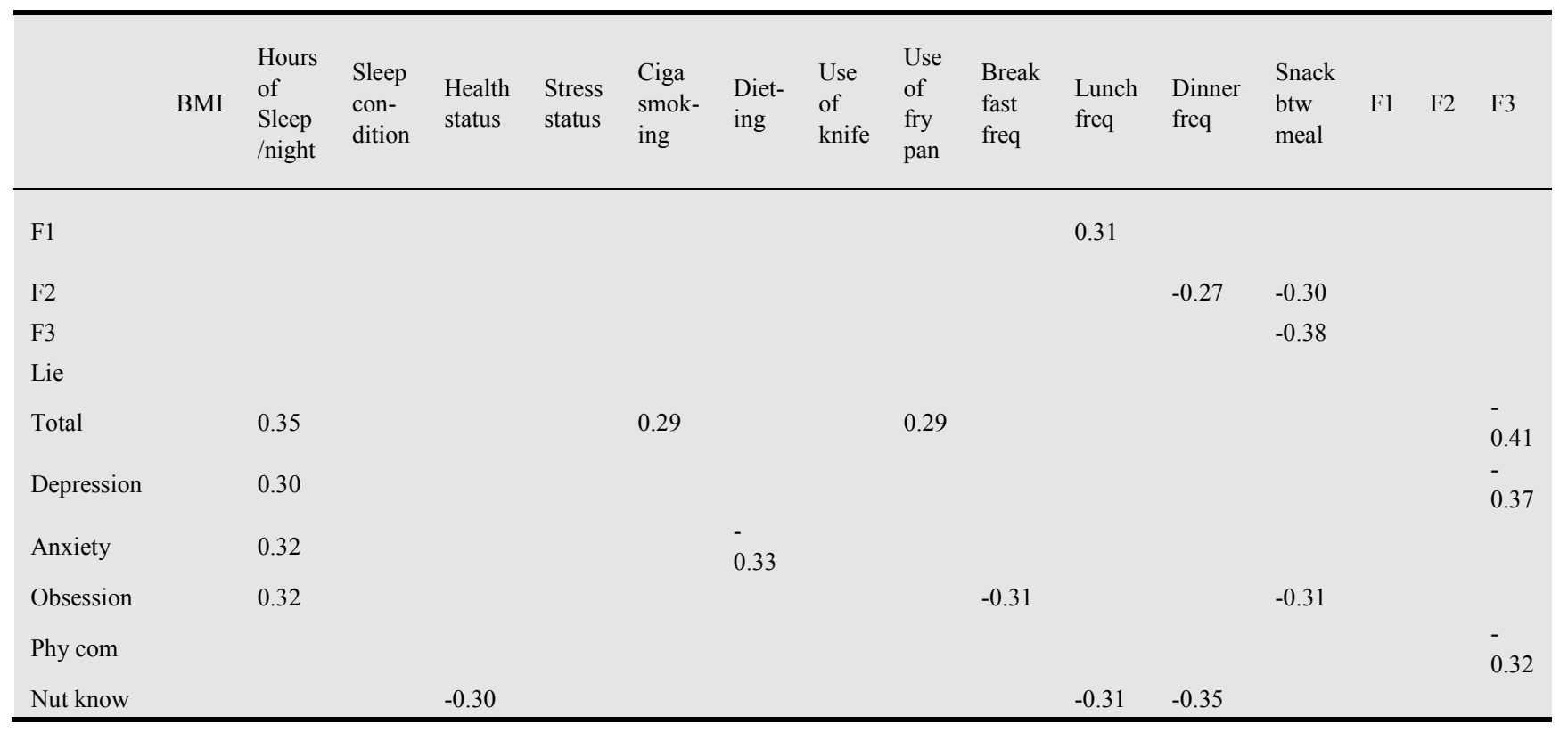




\begin{tabular}{|c|c|c|c|c|c|c|c|c|c|c|c|c|c|c|c|c|}
\hline & BMI & $\begin{array}{l}\text { Hours } \\
\text { of } \\
\text { Sleep } \\
\text { /night }\end{array}$ & $\begin{array}{l}\text { Sleep } \\
\text { con- } \\
\text { dition }\end{array}$ & $\begin{array}{l}\text { Health } \\
\text { status }\end{array}$ & $\begin{array}{l}\text { Stress } \\
\text { status }\end{array}$ & $\begin{array}{l}\text { Ciga } \\
\text { smok- } \\
\text { ing }\end{array}$ & $\begin{array}{l}\text { Diet- } \\
\text { ing }\end{array}$ & $\begin{array}{l}\text { Use } \\
\text { of } \\
\text { knife }\end{array}$ & $\begin{array}{l}\text { Use } \\
\text { of } \\
\text { fry } \\
\text { pan }\end{array}$ & $\begin{array}{l}\text { Break } \\
\text { fast } \\
\text { freq }\end{array}$ & $\begin{array}{l}\text { Lunch } \\
\text { freq }\end{array}$ & $\begin{array}{l}\text { Dinner } \\
\text { freq }\end{array}$ & $\begin{array}{l}\text { Snack } \\
\text { btw } \\
\text { meal }\end{array}$ & F1 & F2 & F3 \\
\hline \multicolumn{17}{|l|}{$\begin{array}{l}\text { Avoid } \\
\text { frying }\end{array}$} \\
\hline $\begin{array}{l}\text { Modify } \\
\text { meat }\end{array}$ & & & & & & & & & & & & 0.28 & & & & \\
\hline \multicolumn{17}{|l|}{$\begin{array}{l}\text { Sub high } \\
\text { fat }\end{array}$} \\
\hline \multicolumn{17}{|l|}{$\begin{array}{l}\text { Replace } \\
\text { meat }\end{array}$} \\
\hline $\begin{array}{l}\text { Avoid fat } \\
\text { as } \\
\text { flavoring }\end{array}$ & & & & & 0.32 & & & & & & & & & & & - \\
\hline $\begin{array}{l}\text { Replace } \\
\text { with fruits } \\
\& \text { veg }\end{array}$ & & & & & & & & & & 0.38 & & & & & & $\begin{array}{l}- \\
0.47\end{array}$ \\
\hline
\end{tabular}

Ciga(cigarette), freq(frequency), bwt (between), F1(healthy eating habits), F2(emotional and personal eating style), F3(consciousness in food safety),Phy com (physical complaint), Nut know(nutrition knowledge), sub(substitute), veg (vegetable).

As for female, the correlation pattern reveled that eating attitudes factor score was with meal frequency (lunch and dinner) and snacking between meals. UPI subscale showed significant association with life style and eating attitudes factor score F3. Fat related habits (avoid fat as flavoring, and replace with fruits and vegetables) showed negative associations with eating attitudes factor score F3 (Table 13).

\section{Discussion}

This study is the first to present a detailed report on the eating habits, of university students from Delta State, Southern Nigeria. Nutritional knowledge, fat-related habits, eating attitudes, meal frequency, and personality traits were compared in relation to sexes. These results make an important contribution to our understanding of the university student eating behavior in Southern Nigeria. This research focused on university student; an important population which is at a key crossroads in nutritional health. A detailed literature searched showed that there are no published reports regarding eating habits of university student in Delta state, Nigeria. Existing reports comes from studies either from a different geographic region [21], or focused just on the prevalence of overweight and obesity [22].

Results from this study shows that based on BMI classification of weight status, about half of the students were of normal weight and there was no sex difference with respect to weight status of the students. The prevalence of overweight (obese inclusive) is about $40.4 \%$ for male and $37.7 \%$ for female students. Although, this finding is higher than previously reported prevalence among university student in South-West Nigeria [22,23], high prevalence of overweight among university students have also been reported in other countries $[9,24,25]$. The possible explanation for the difference could be the on-going nutritional and epidemiologic transitions [26]. Secondly, the societal perception in most African countries including Nigeria considers being overweight or obese as an evidence of good living and richness. Also, the Calabar and Efik tribes in Southern Nigeria has the tradition of sending young women to fattening houses where they are lock-up in a room and fed with large quantity of high dense carbohydrates for over three months in order to get fat before marriage.

In this study, data on frequency of eating meal showed that majority of the students eat breakfast, lunch and dinner regularly. Although, there was slight sex variation in the proportion of meal frequency, no significant difference was observed among sex. Though, $55.8 \%$ and $58.9 \%$ of male and female respectively tended to eat lunch daily, the overall level of the frequency of daily meal intake among the studied population is considerable good and could be considered a healthy diet practice. The breakfast regularity seems to be higher than that reported for Lebanese students [9], Saudi Arabian students [27], and Malaysian students [28], but lower compared to report for Chinese and Japanese students [11,29]. No significant difference between male and female students was observed for frequency of breakfast consumption, although in most Europe countries females eat breakfast more than do males [30].

The rate of always snacking in between meals was relatively higher among females (25.0\%) compared to males $(23.1 \%)$. The snacking rate among the study population was lower than that reported for Lebanese students [9]. Smoking of cigarettes was not common among the students. The prevalence of smoking is low 
compared to theprevalence among university students in many European countries [31].In addition to coping with the normal stressors of everyday life, university students must deal with stressors specific to their academics. In this study, about half of the students were within normal level of stress. This may imply they have already well adapted to cope with student life and associated stressors. This study showed that the average duration of night sleep among students was 7.9 hours. Earlier studies in Asian countries reported average sleep duration among Korean college students to be 6.7 hours [32], and 6.9 hours for Chinese students [33]. Thus the average sleeping duration observed among these students was about 1 hour higher than the reported averages among students from Asia.

Although dieting is becoming a popular phenomenon among university students to achieve or maintain a healthy weight, data from this study shows that dieting is not a common practice among the studied population, $71.2 \%$ male and $69.6 \%$ of female students reported not being on diet. The low prevalence of dieting among the students suggest that the risk of exhibiting body disordered attitude towards body image is low and that participants of the study are more satisfied with their weight. In other countries, contrasting findings have been reported, for example, Méndez-Hernández et al., [34]reported a dieting rate of $40.0 \%$ among university students in Mexico. Given the low prevalence of dieting observed in this study, it is reasonable to assume that the students had fairly good selfimage.

Of the 36 items related to eating attitudes that were investigated in this study, the means of these three items $(6$, 10 , and 15) were higher for female students than for male students. Item 10 (I try not to eat too much), related to being mindful of the quantity of food eaten. This is an eating habit common among female most probable due to their high concern about body image and shape [35], and their higher propensity to either lose weight or avoid gaining weight. Generally, the pictures of movie stars and models in fashion magazines and mass media have a strong impact on females' body shape and image perception [36]. University female students see the shape and weight of fashion models as the ideal body shape and figure to attain. It is expected that female students with such strong body weight/shape perception may tend to place emphases on restriction of large volume of food. Furthermore, the mean score for item 6(the amount of my food intake varies depending on my mood) was significantly higher for female students. Taken these two factors together, it implies that female student from Southern Nigeria are conscious not to engage in overeating however, the quantity of their food is moderated by their mood. This confirmed earlier report that females share a great interest in the interactions between food intake and mood, and with the general assumption that emotions may alter eating behaviors $[37,38]$. Studies have shown that an induction of negative mood leads to an increase of food intake [37,39].

Results of the factor analysis of eating attitudes revealed three striking factors. The factors had appreciable alpha coefficients for factors 1 and 2 respectively. The first factor was related to healthy eating habits and the second factor was related to emotional and personal eating style while the third factor relates consciousness in food safetyhad the highest factor loading. Practicing good eating habits is highly essential to maintain good health. Mores so, female had significant higher mean factor score for F3 than male. This may indicate that female students were more likely to worry about the food safety issues and tended to observe some measures such reading of food labels and checking expiring date. More so, the significant higher scores for "I feel uneasy about trusting imported food" in female further support the higher level of consciousness in food safety among female students. This result confirmed the prior findings of Blair et al. [40] that females are more safety conscious in safe behavior and beliefs.

The FDHQ subscale showed that the students engaged in a variety of the subscale behaviors to reduced fat intake. These includes avoiding frying, modify meat to be low in fat, substitute high fat food with low fat, replace meats, avoid fat as flavoring and replaced high fat foods with fruits and vegetables. The lower mean fat-related dietary subscale scores (indicates lower fat intake and by implication higher practice of the behavior). Of the six subscales, there were significant lower scores for modifying meats to be low in fat and substitute high fat food with low fat among male. This suggests that male students are more likely to use these behaviors to reduce fat intake than female students. The sex differences observed in this study do not agree with the findings of Noia et al. [41] who reported that there was no sex difference in the fat-related behavior in African American adults. The difference in setting and participants may be a possible explanation for difference in the findings. However, the observance of lower mean scores for modifying meats to be low in fat and substitute high fat food with low fat is in agreement with the report of Gans et al. [42] that African adults commonly practice modification as a means of fat reduction. Also, lower subscale scores for modifying foods to be low in fat have been reported among adults $[18,19]$.

The study also assessed mental health of university students using the university personality inventory (UPI). Of the 60 items, only 6 items $(1,12,15,16,29$ and 41) showed significant sex differences. The UPI items were classified into six subscales; UPI lie, total, depression, anxiety, obsession and physical complaint. The scores of the UPI subscale suggest that the students were in good mental health state. There was no significant sex difference in the mean scores of the subscale of the UPI. This concurs with the findings of Tominaga et al. [43] who found no significant differences in the mean scores of each UPI scale between male and female students, except for physical complaint items.

The correlation analyses results showed some distinctions. For male, higher scores for F3 relates to not dieting. This means greater level of consciousness in food 
safety results to lower tendency of dieting. This is expected as students with higher consciousness in food safety are most likely to be aware of negative implication of unhealthy dieting. For female, anxiety increases the tendencies for dieting. A possible explanation could be that, female students are more worried and dissatisfied with their body weight and self-image, thus are more likely to engage in weight loss programs. As for frequency of meal, healthy eating habit in female was associated with lower frequency of eating lunch. This is an unexpected finding, as it would be expected that high scores for healthy eating habits should relate to higher frequency in lunch intake. One possible explanation to this result is that healthy eating habits may not necessarily translate to higher rate of eating lunch. Secondly, it could be that the students may not have the time to eat lunch due to busy lectures and academic schedules. The lecture time tables for universities in Nigeria do not make provision for lunch time. This could be a possible reason for the low frequency of lunch intake observed among the study population. Furthermore, for female, emotional and personal eating style increased the tendency for eating dinner. Refereeing to the items that constitute this factor (Table 7), emotional eating in this case do not implies that the student eat dinner to reflect a negative emotions but may be due to sight of someone eating (When I see a person eating, I want to eat as well). It was found that frequency of snacking between meals in male and female was significantly related with emotional and personal eating style and consciousness in food safety. This suggest that emotional eating could trigger snacking and the relationship between consciousness in food safety implies that individuals with the habitual tendency to snack between meal when being emotional may not necessarily be aware of the unconscious link between negative emotions and the corresponding behavioral response (snacking).

Also, among male students, depression tends to be related to low snacking. This observation is contrarily to previous report that associated depression with increased snaking [44]. A possible explanation could be that the level of appetite during moment of depression could moderate the degree of snacking. More so, for male students, there were notable significant correlations between FDHQ subscales scores with frequency of snacking among and eating attitudes factor (F2 and F3). High tendency for fat avoidance related to low frequency of snacking but associate positively with emotional and personal eating style, and consciousness in food safety. Also in male students, higher scores for UPI subscale correlated positively with emotional and personal eating style suggesting that bad mental health may increase the tendency for emotional eating. For female, the trend of the association between UPI subscale and F3, as well as fatrelated subscale and F3 was reversed and showed no striking associations. The reasons for these patterns of associations are largely unclear and difficult to explain. Further study may be required to clarify these associations.
Just like any other study, there is a limiting factor which might limit the generalization of this study. The use of small sample of students from only Abraka campus may not be a true representation of university students. Further studies should explore a far larger sample as well as extending to other Campuses of the University. Therefore, given the limitation mentioned results of this study should be interpreted with caution.

In conclusion, eating behaviors are influenced by a variety of factors, including life style factors and mental health state. Associations exist among these factors and eating habits. However, patterns of association suggest a modulating effect of sex on eating behaviors. Efforts aimed at modifying unhealthy eating habits may benefit from a tailored approach, which takes into account individual differences in these factors.

\section{Acknowledgments}

This paper was born out of my M. Sc studies (April, 2010-March, 2013). I am grateful to Dr. M. Tominaga for mentoring me through my graduate studies and for her useful comments. Special thanks to Siebold University, Nagasaki Japan for provision of funding for data collection. Also, we sincerely appreciate the participation of the students.

\section{Conflict of Interest}

The authors declare no conflict of interest.

\section{Authors' Contributions}

$\mathrm{JN}$ is the principal investigator and was responsible for conception of the study, data imputing, analysis and interpretation as well as writing of the thesis. JCN assisted in data imputing, cleaning analysis and interpretation and finalizing the manuscript. KHN was responsible for data collection and coordination of the field work.

\section{References}

[1] World Health Organization (WHO). Obesity and overweight World Health Organization, 2012. http://www. who. $\mathrm{int} /$ mediacentre/factsheets/fs311/en/ (accessed last on October 9, 2013).

[2] Cavalli-Soforza LT, Rosman A, de BoerAS, Darnton-Hill I. Nutritionalaspects of changes in disease patters in Western Pacific region. Bull. World HealthOrgan. 1996, 74(3), $307-$ 318.

[3] Drewnowski A, Popkin BM. The nutrition transition: trends in the globaldiet. Nutritional Reviews, 1997, 55(2), 31-43.

[4] Triches RM, Giugliani RJ. Obesity, eating habits and nutritional knowledgeamong school children. Rev SaủdePủblica, 2005, 39(4), 1-7. 
[5] Chourdakis M, Tzellos T, Papazisis G, Toulis K, KouvelasD. Eating habits, health attitudes and obesity indices among medical students in northern Greece. Appetite, 2010; 55(3):722-725.

[6] Li R, Serdula M, Bland S, Mokdad A, Bowman B, NelsonD. Trends in fruit and vegetable consumption among adults in 16 US states: behavioral risk factor surveillance system, 1990-1996. Ame. J. Public Health, 2000, 90(5), 777-781.

[7] Liebman M, CameronBA, Carson DK, Brown DM, Meyer SS. Dietary fat reductionbehaviors in college students: relationship to dieting status, gender and key psychosocial variables. Appetite, 2001, 36, 51-56.

[8] Wardle, J. ; Haase, A. M. ; Steptoe, A. ; Nillapun, M. ; Jonwutiwes, K. ; Bellisle, F. Gender differences in food choice: the contribution of health beliefs and dieting. Annalsof Behavioral Med. 2004, 27(2), 107-16.

[9] Yahia N, Achkar A, Abdallah A, RizkS. Eating habits and obesity among Lebanese university students. Nutr. J. 2008, 7: 32.

[10] Osaka R, Nanakorn S, Sanseeha L, Nagahiro C, Kodama N. Healthy dietary habits, body mass index, and predictors among nursing students, northeast Thailand. Southeast Asian J. Tropical Med. Public Health, 1999, 30(1), 115-121.

[11] Sakamaki R, Amamoto R, Mochida Y, Shinfuku N, Toyama $\mathrm{K}$. A comparative study of food habits and body shape perception of university students in Japan and Korea. Nutr. J. $2005,4,31$.

[12] Malinauskas BM, Raedeke TD, Aeby VG, Smith JL, Dallas MB. Dieting practices, weight perceptions, and body composition: a comparison of normal weight, overweight, and obese college females. Nutr. J. 2006, 5, 11.

[13] Kim H, Han SN, SongK, Lee H. Lifestyle, dietary habits and consumption pattern of male university students according to the frequency of commercial beverage consumptions. Nutr. Research Practice, 2011, 5(2), 124-131.

[14] Tominaga M, Taguchi M, Suzuki A, Ikawa Y, Youn H, Cho $\mathrm{K}$, Scherling J, Roth R. Differences in self-assessment regarding eating behaviors among female university students living in Japan, Korea, and Austria. Food Nutr. Sciences, 2012, 3, 1673-1681.

[15] Gan WY, Mohd NM, Zalilah MS, Hazizi AS. Differences in eating behaviors, dietary intake and body weight status between male and female Malaysian university students. Malaysian J. Nutr, 2011, 17(2), 213-228.

[16] Tominaga M, Suzuki A, Taguchi M, Takemoto H, Yoon H, Cho K, Ikawa Y. Comparative study of eating habits of university students in Japan and Korea. J. for the Integrated Study of Dietary habits, 2009, 20(2), 111-120.

[17] Kristal AR, Shattuck AL, Patterson RE. Differences in fatrelated dietary patterns between black Hispanic, and white women results from the women's health trial feasibility study in minority populations. Public Health Nutr. 1999, 2(3), 253-262.

[18] Neuhouser ML, Thompson B, Coronado GD, Solomon CC. Higher fat intake and lower fruit and vegetable intakes are associated with greater acculturation among Mexicans living in Washington State. J. Ame Dietetic Association, 2004, 104, 51-57.
[19] Melnik TA, Spence MM, Hosler AS. Fat-related dietary behaviors of adult Puerto Ricans, with and without diabetes, in New York City. J. Ame Dietetic association, 2006, 106(9), $1419-1425$.

[20] Yoshida T, Ichikawa T, Ishikawa T, Hori M. Mental health of visually and hearing impaired students from the viewpoint of the University Personality Inventory. Psychiatry and Clin. Neurosciences, 1998, 52(4), 413-418.

[21] Nnanyelugo DO, Okeke EC. Food habits and nutrient intakes of Nigerian university students in traditional halls of residence. J. Ame College Nutr, 1987, 6(5), 369-374.

[22] Olusanya JO, Omotayo AO. Prevalence of Obesity among undergraduate students of Tai Solarin University of Education, Ijagun, Ijebu-Ode. Pakistan J. Nutr. 2011, 10 (10), 940-946.

[23] Olaoye OR, Oyetunde OO. Perception of weight and weight management practices among students of a tertiary institution in south west NigeriaJ. Applied Pharm. Science, 2012, 2(1), 81-84.

[24] Al-Isa AN. Obesity among Kuwait university students: an explorative study. The J. the Royal Soc. for the Promotion of Health, 1999, 119(4), 223-227.

[25] Musaiger AO, Lloyd OL, Al-Neyadi SM, Bener AB. Lifestyle factors associated with obesity among male university students in the United Arab Emirates. Nutr. Food Science, 2003, 33(4), 145-147.

[26] Wahab KW, Sani MU, Yusuf BO, Gbadamosi M, Gbadamosi A, Yandutse M. Prevalence and determinants of obesity - a cross-sectional study of an adult Northern Nigerian population. International Archives of Med. 2011, 4, 10.

[27] Al-Rethaiaa AS, Fahmy AA, Al-Shwaiyat NM. Obesity and eating habits among college students in Saudi Arabia: a cross sectional study. Nutr J. 2010, 9, 39.

[28] Abdull Hakim, NH. Muniandy ND. Danish, A. Nutritional status and eating practices among university students in selected universities in Selangor, Malaysia. Asian J. Clinical Nutr. 2012, 41(3), 77-87.

[29] Sakamaki R, Toyama K, Amamoto R, Liu C, Shinfuku N. Nutritional knowledge, food habits and health attitude of Chinese university students-a cross sectional study. Nutr. J. $2005,4,4$.

[30] Corder K, van Sluijs, EMF, Steele RM, Stephen AM. Dunn $\mathrm{V}$, Bamber D, Ekelund U. Breakfast consumption and physical activity in British adolescents. British J. Nutr. 2011, 105(2), 316.

[31] Steptoe A, Wardle J, Cui W, Bellisle F, Zotti AM, BaranyaiR, Sanderman R. Trends in smoking, diet, physical exercise, and attitudes toward health in European university students from 13 countries, 1990-2000. Preventive Medicine, 2002, $35,97-104$.

[32] Ban DJ, Lee TJ. Sleep duration, subjective sleep disturbances and associated factors among university students in Korea. J. Korean Med. Science, 2001, 16(4), $475-80$.

[33] Tsui YY, Wing YK. A study on the sleep patterns and problems of university business students in Hong Kong. J. Ame. College Health, 2009, 58(2), 167-176. 
[34] Méndez-Hernández P, Dosamantes-Carrasco D, Lamure M, López-Loyo P, Hernández-Palafox C, Pineda-Pérez D, Flores Y, Salmerón J. Weight-loss practices among university students in Mexico. Inter. J. Public Health, 2010, 55(3). 221-225.

[35] Yannakoulia M, Karayiannis D, Terzidou M, Kokkevi A, Sidossis LS. Nutrition-related habits of Greek adolescents. Euro J. Clinical Med. Nutr. 2004, 58(4), 580-586.

[36] Field AE, Cheung L, Wolf AM, Herzog DB, Gortmaker SL, Colditz, GA. Exposure to the mass media and weight concerns among girls. Pediatrics, 1999, 103(3), 36.

[37] Canetti L, Bachar E, Berry EM. Food and emotion. Behavioral Processes, 2002, 60, 157-164.

[38] Turner SA, Luszczynska A, Warner L, Schwarzer R. Emotional and uncontrolled eating styles and chocolate chip cookie consumption. A controlled trial of the effects of positive mood enhancement. Appetite, 2010, 54, 143-149.

[39] Tice DM, Bratslavsky E. Giving in to feel good: the place of emotional regulation in the context of general self-control. Psychological Inquiry, 2000, 11, 149-159.
[40] Blair EH, Seo DC, Torabi MR., Kaldahl MA. Safety beliefs and safe behavior among mid-western college students. J. Safety Research, 2004, 35(2), 131-140.

[41] Di Noia J, Contento IR, Schinke SP. Fat avoidance and replacement behaviors predict low-fat intake among urban African American adolescents. Nutr. Research, 2008, 28(6), 358-363.

[42] Gans KM, Burkholder GJ, Risica PM, Lasater TM. Baseline fat-related dietary behaviors of White, Hispanic, and Black participants in a cholesterol screening and education project in New England. J. Ame. Dietetic Association, 2003, 103, 699-706.

[43] Tominaga M, Shimizu M, Mori T, Kodama K, Sato K. Relationship between life style focusing on eating habits and mental health of junior and high school students, and university students. J. Home Economics of Japan, 2001, 52(6), 499-510.

[44] Ouwens M A, VanStrien T, Van Leeuwe, JFJ. Possible pathways between depression, emotional and external eating a structural equation model. Appetite, 2009, 53(2), 245-248. 